\title{
Identification and Characterization of a Carlavirus Causing Veinal Necrosis of Coleus
}

Dimitre S. Mollov and Maya C. Hayslett, Department of Plant Pathology, Kari A. Eichstaedt, Department of Agronomy and Plant Genetics, and Noelle G. Beckman, Department of Ecology, Evolution, and Behavior, University of Minnesota, St. Paul 55108; Margery L. Daughtrey, Department of Plant Pathology, Cornell University, Riverhead, NY 11901; and Ben E. Lockhart, Department of Plant Pathology, University of Minnesota

\begin{abstract}
Mollov, D. S., Hayslett, M. C., Eichstaedt, K. A., Beckman, N. G., Daughtrey, M. L., and Lockhart, B. E. 2007. Identification and characterization of a carlavirus causing veinal necrosis of coleus. Plant Dis. 91:754-757.

A filamentous virus identified in coleus (Coleus $\times$ hybrida) in Minnesota and New York was found to cause veinal necrosis in coleus, although this symptom was observed only under certain conditions. The virus was transmitted readily by mechanical inoculation to coleus and Nicotiana spp. and was not transmitted by Myzus persicae. The particles of the coleus virus had a modal length of $640 \mathrm{~nm}$ and a single capsid protein with an estimated molecular mass of $34 \mathrm{kDa}$. The amino acid sequence of the coat protein region of the coleus virus genome had significant similarities only to the corresponding domain of carlaviruses. Based on virion morphology, capsid protein size, genome size and organization, amino acid sequence, and phylogenetic analyses, the coleus virus, which was named provisionally Coleus vein necrosis virus (CVNV), was concluded to be a new definitive member of the genus Carlavirus. A 2-kb fragment of the $3^{\prime}$ terminus of the CVNV genome sequence is accessible under accession number DQ915963 in GenBank.
\end{abstract}

Coleus (Coleus $\times$ hybrida) is a widely used landscape ornamental that is valued for its brightly colored foliage and has been listed as the tenth most important bedding plant in the United States (14), valued at $\$ 12.3$ million annually. Although coleus can be grown from seed, the major portion of the crop enters the bedding plant trade in the form of vegetatively propagated stock. Viral infection in coleus, as in other clonally propagated crops, can pose significant economic problems due to reduced consumer acceptability and market value. Cucumber mosaic virus (CMV) and Impatiens necrotic spot virus (INSV) are the only viruses known to occur naturally in coleus. CMV causes mosaic, ringspot, and oak-leaf symptoms (10). INSV causes round necrotic spots (unpublished data). Coleus also has been reported to be infected with a viriod which induces no apparent symptoms (13). In the summer of 2005, plants of several coleus cultivars showing abnormal leaf coloration suggestive of viral infection were selected from a coleus collection at the University of Minnesota. Numerous filamentous virus-like particles were observed by transmission

\section{Corresponding author: Ben Lockhart}

E-mail: lockh002@umn.edu

Accepted for publication 18 January 2007.

doi:10.1094/PDIS-91-6-0754

(C) 2007 The American Phytopathological Society electron microscopy (TEM) in negatively stained partially purified extracts prepared from leaf tissue from abnormal, but not from normal-looking, plants. In spring 2006, plants of the coleus cv. Copper Glow showing vein necrosis and ring patterns (Fig. 1) in a commercial greenhouse in New York were found to contain virus-like particles similar in morphology and other properties to those occurring in coleus in Minnesota. No other virus-like particles were detected in symptomatic coleus plants from either Minnesota or New York. The study reported here was undertaken to determine the identity, properties, and pathogenicity of the virus occurring in coleus in Minnesota and New York.

\section{MATERIALS AND METHODS}

Virus source, transmission, and host range. The virus used in this study was obtained initially from plants of an unidentified coleus cultivar in a plant collection at the University of Minnesota. The virus was propagated in Nicotiana benthamiana, which served as virus source for subsequent experiments. Transmission tests were done by mechanical inoculation of Carborundum-dusted leaves of healthy indicator plants using crude sap extracts from infected $N$. benthamiana prepared in $100 \mathrm{mM}$ phosphate buffer, $\mathrm{pH} 7.4$, containing $0.5 \%$ (vol/vol) 2-mercaptoethanol. In all, 5 to 10 healthy plants of each indicator plant species were tested. Aphid transmission tests were done using nonviruliferous apterae of Myzus persicae that were starved for $1 \mathrm{~h}$ and allowed a 2- to 10-min acquisition access period on infected $N$. benthamiana, after which they were transferred to healthy coleus and $N$. benthamiana test plants. After an inoculation access period of 12 to $16 \mathrm{~h}$, the aphids were killed with insecticide (Pirimor). Indicator plants used in mechanical or aphid transmission tests were kept in the greenhouse for 6 to 16 weeks post inoculation. They were observed for symptom expression and assayed for presence of virus using serological assays described below. A virus associated with veinal necrosis symptoms in the coleus cv. Copper Glow in New York (Fig. 1) had filamentous particles similar in morphology to those of the Minnesota coleus virus, and was studied in order to determine its relationship to the latter. No other virus-like particles were detected by TEM in partially purified extracts of symptomatic Copper Glow plants.

Virion purification, electron microscopy, capsid protein size measurement, and antiserum production. Virions were extracted and purified from infected coleus and $N$. benthamiana leaf tissue by differential centrifugation and isopycnic densitygradient centrifugation on $\mathrm{Cs}_{2} \mathrm{SO}_{4}$ as described (6). Partially purified virion preparations were examined by TEM following negative staining with $2 \%$ (wt/vol) sodium phosphotungstate, $\mathrm{pH} 7.0$, containing bacitracin (PTA) at $250 \mu \mathrm{g} / \mathrm{ml}$. Microscope magnification was calibrated using the crystal lattice spacing of stained catalase

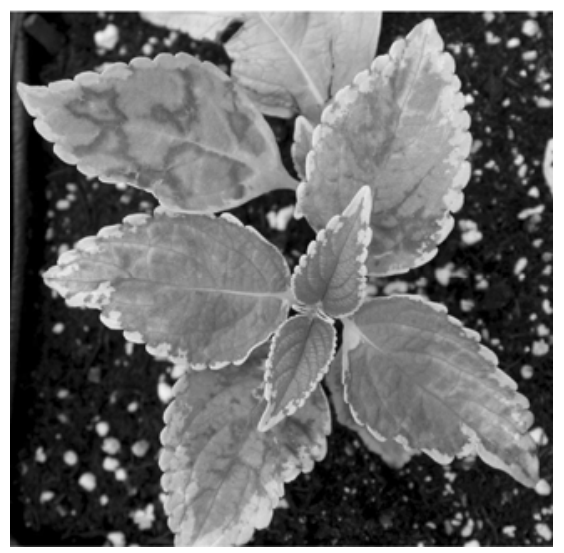

Fig. 1. Symptoms observed in Coleus blumei cv. Copper Glow infected naturally with Coleus vein necrosis virus. 
crystals (15). The molecular mass of the virion capsid protein $(\mathrm{CP})$ was estimated by sodium dodecyl sulfate polyacrylamide gel electrophoresis (SDS-PAGE) (12) using a 10 - to $200-\mathrm{kDa}$ Benchmark protein ladder (Invitrogen) as size markers. An antiserum against purified virions was raised in a New Zealand White rabbit using a schedule of subcutaneous immunizations with purified virion antigen emulsified in an equal volume of Titermax Gold adjuvant (Sigma-Aldrich, St. Louis). Injections were administered on days 1 (5 mg), $14(2.5 \mathrm{mg})$, and 28 (2.5 $\mathrm{mg}$ ). Antiserum samples obtained from blood samples collected 45 to 80 days after the initial immunization were tested by indirect enzyme-linked immunosorbent assay (ELISA; 11) and were used subsequently for detection of the coleus virus by immunosorbent electron microscopy (ISEM) using partially purified leaf tissue extracts (1) and by double-antibody sandwich (DAS)-ELISA) using the standard protocol (5).

Genomic sequence and phylogenetic analyses. The nucleotide sequence of a portion of the $3^{\prime}$ end of the viral genome was obtained using cDNA synthesized from total RNA extracted from infected $N$. benthamiana leaf tissue using a Qiagen RNeasy kit and primer M4T as described (3) followed by polymerase chain reaction amplification using the primers M4 (3) and

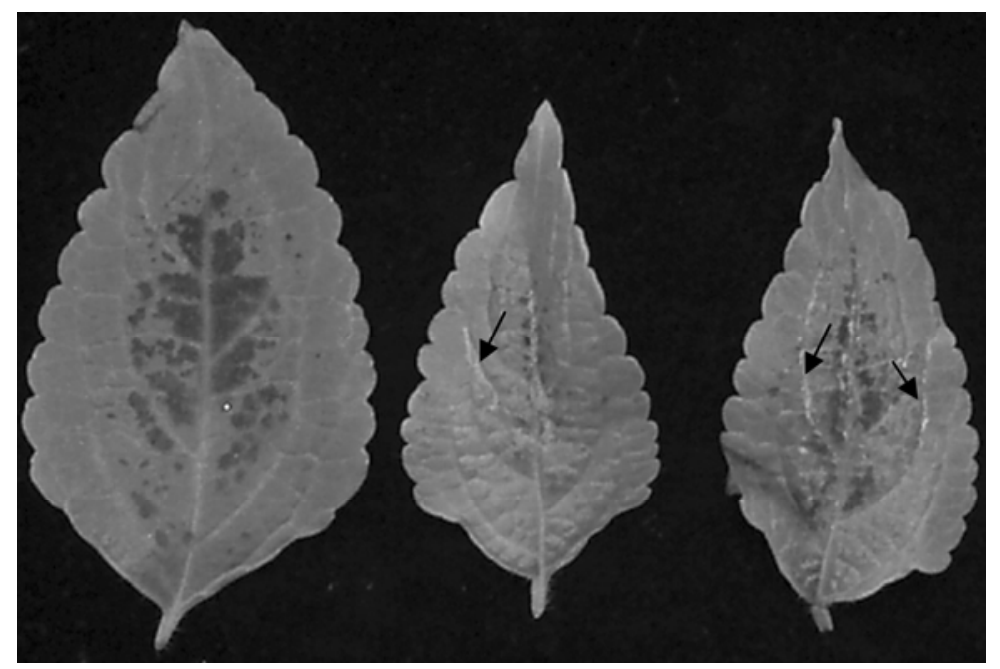

Fig. 2. Vein necrosis symptoms (black arrows) observed in coleus infected by mechanical inoculation with Coleus vein necrosis virus (CVNV) propagated in Nicotiana benthamiana (left, healthy leaf; middle and right leaves, infected with CVNV).
pCar 1 (4). The amplicon was gel purified using a Qiagen Gel Extraction kit and cloned using a TopoTA cloning kit (Invitrogen). Plasmid DNA from five selected colonies was sequenced using an $\mathrm{ABI}$ 3730XL automated sequencer at the University of Minnesota BioMedical Genomics Center. Nucleotide and amino acid

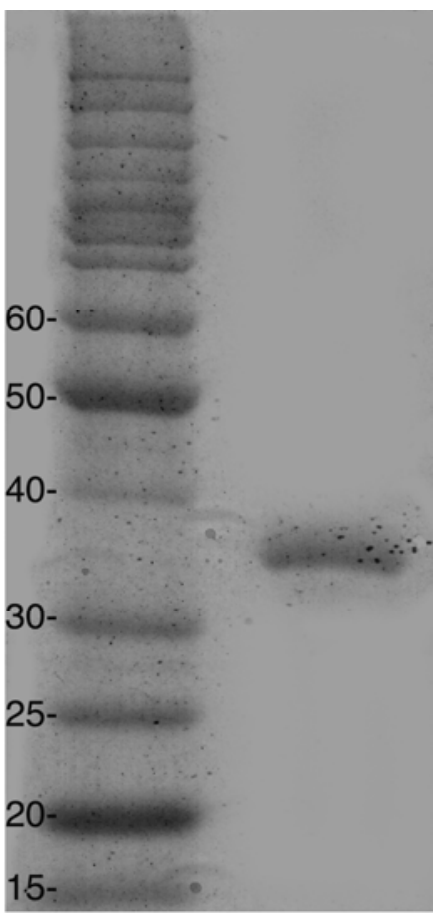

Fig. 3. Estimation of molecular mass of Coleus vein necrosis virus capsid protein by sodium dodecyl sulfate polyacrylamide gel electrophoresis. Molecular mass $(\mathrm{kDa})$ of size markers (left) are indicated.

Table 1. Host range and reaction of indicator plants to mechanical inoculation with Coleus vein necrosis virus

\begin{tabular}{|c|c|c|c|c|}
\hline Species name & Common name & Family & Local reaction & Systemic reaction $^{a}$ \\
\hline Coleus $\times$ hybrida & Coleus & Labiatae & $+/ \mathrm{VN}^{*}$ & $+/ \mathrm{VN}^{*}$ \\
\hline Lamium maculatum & Deadnettle & Labiatae & - & - \\
\hline Lavandula angustifolia & Lavender & Labiatae & - & - \\
\hline Mentha spicata & Mint & Labiatae & _- & _- \\
\hline Monarda didyma & Bee-Balm & Labiatae & - & - \\
\hline Nepeta cataria & Catnip & Labiatae & - & - \\
\hline Ocimum basilicum & Basil & Labiatae & - & - \\
\hline Origanum vulgare & Oregano & Labiatae & - & - \\
\hline Physostegia virginiana & Obedient Plant & Labiatae & - & - \\
\hline Rosemarnium officinalis & Rosemary & Labiatae & - & - \\
\hline Salvia officinalis & Sage & Labiatae & - & - \\
\hline Stachys byzantina & Lamb's Ear & Labiatae & - & - \\
\hline Gomphrena globosa & Globe amaranth & Amaranthaceae & - & - \\
\hline Chenopodium quinoa & Lambsquarter & Chenopodiaceae & - & - \\
\hline Zinnia elegans & Zinnia & Compositae & - & - \\
\hline Brassica napus & Turnip & Cruciferae & - & - \\
\hline Cucumis sativus & Cucumber & Cucurbitaceae & - & - \\
\hline Phaseolus vulgaris & Bean & Leguminosae & - & - \\
\hline Pisum sativum & Pea & Leguminosae & - & - \\
\hline Vigna unguiculata & Cowpea & Leguminosae & - & - \\
\hline Nicotiana benthamiana & Tobacco & Solanaceae & +/ChlLL & $+/ \operatorname{Mos}$ \\
\hline N. clevelandii & Tobacco & Solanaceae & +/ChlLL & +/Mos \\
\hline N. tabacum & Tobacco & Solanaceae & +/VN, NecRSP & +/VN, NecRSP \\
\hline N. glutinosa & Tobacco & Solanaceae & - & - \\
\hline Petunia $\times$ hybrida & Petunia & Solanaceae & - & - \\
\hline Lycopersicon esculentum & Tomato & Solanaceae & - & - \\
\hline
\end{tabular}

a Explanation of symbols: $*=$ observed under certain conditions, $+=$ infection, $-=$ no infection, $\mathrm{VN}=$ vein necrosis, ChlLL $=$ chlorotic local lesions, Mos $=$ mosaic, and NecRSP $=$ necrotic ringspots. 


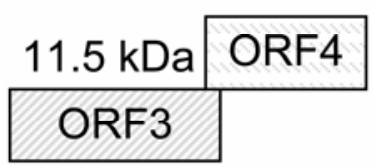

Fig. 4. Organization of putative protein-encoding domains within the 2-kb $3^{\prime}$ terminus of the Coleus vein necrosis virus genome. ORF $=$ open reading frame.

Table 2. Percent amino acid identity between coat protein regions of Coleus vein necrosis virus and selected carlaviruses

\begin{tabular}{lc}
\hline Virus & Identity (\%) \\
\hline Alfalfa latent carlavirus & 39.5 \\
Carnation latent virus & 64.1 \\
Cowpea mild mottle virus & 39.9 \\
Garlic common latent virus & 62 \\
Garlic latent virus & 36 \\
Garlic virus I & 45.5 \\
Helenium virus $S$ & 64.4 \\
Hippeastrum latent virus & 38.4 \\
Narcissus common latent virus & 36.6 \\
Pea streak virus & 39.8 \\
Poplar mosaic virus & 37.1 \\
Potato virus $M$ & 37.2 \\
Potato virus $S$ & 34.4 \\
Shallot latent virus & 45.8 \\
\hline
\end{tabular}

sequence analysis were performed with SeqMan II (DNAStar), then submitted to BLAST-x and BLAST-p searches of GenBank (2). The CP amino acid sequence was compared with those of the following carlaviruses: Alfalfa latent carlavirus, (AAK85160), Carnation latent virus (CAA36854), Cowpea mild mottle virus (AAB94082), Garlic common latent virus (BAA25782), Garlic latent virus (CAA57047), Garlic virus 1 (BAA05926), Helenium virus $S$ (Q00556), Hippeastrum latent virus (AAZ15110), Narcissus common latent virus (CAC85384), Pea streak virus (AAK40109), Poplar mosaic virus (CAA46226), Potato virus $M$ (AAB81272), Potato virus $S$ (CAI06117), and Shallot latent virus (BAA25779). Multiple sequence alignments were prepared using MUSCLE (7). Phylogenetic analysis and bootstrap values were done by neighbor-joining using Paup 4.0 to determine the relation of the coleus virus to known carlaviruses based on the $\mathrm{CP}$ amino acid sequence.

\section{RESULTS}

Virus transmission and host range. The Minnesota coleus virus was transmitted by mechanical inoculation to five of five healthy test plants of coleus, $N$. benthamiana, $N$. clevelandii, and $N$. tabacum. Vein-necrosis symptoms (Fig. 2) developed in coleus grown at low light intensity, when leaves remained green. At higher light intensity, the foliage developed intense red, purple, and yellow coloration, and neither vein necrosis nor any other discernible symptom was observed. The coleus virus did not induce symptoms and was not detected by ISEM or DAS-ELISA

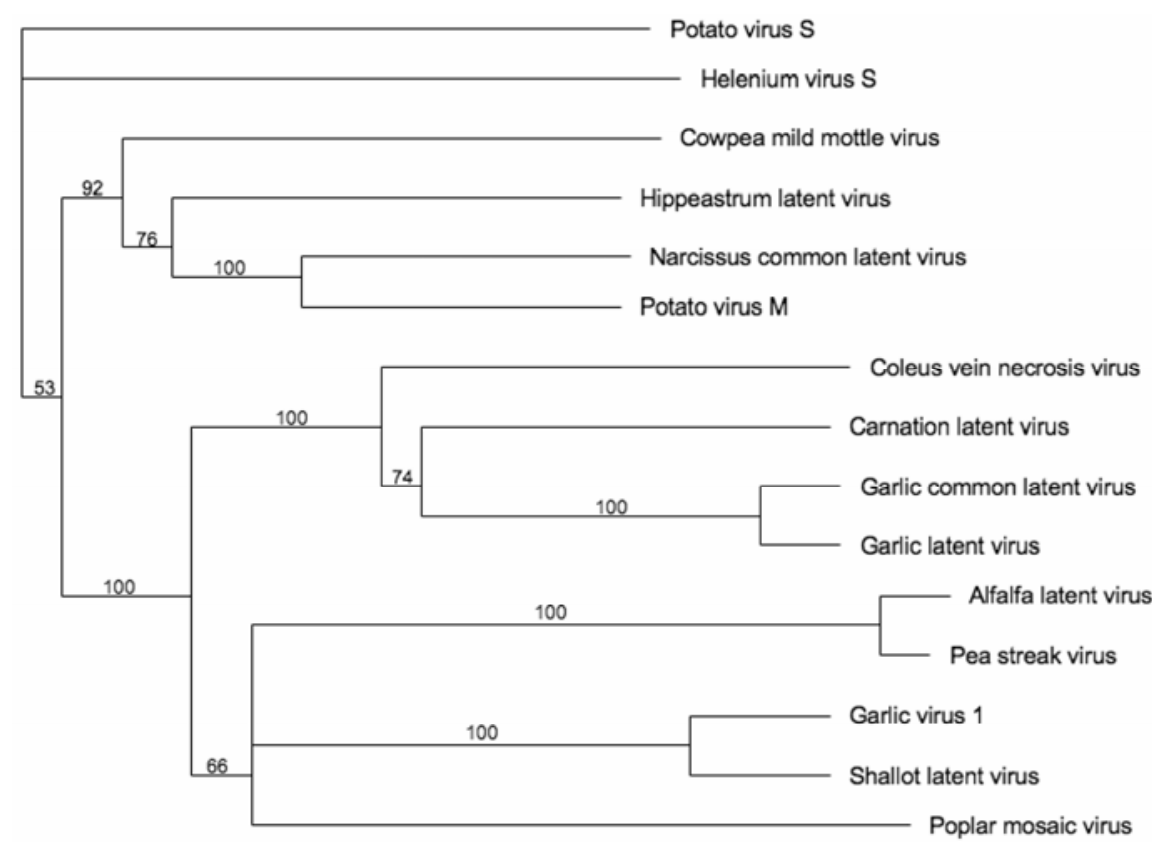

Fig. 5. Phylogenetic relationship of the Coleus vein necrosis virus to known carlaviruses based on coat protein amino acid sequence homology.

in either inoculated leaves or new growth of any other indicator plants. The results of mechanical transmission tests are summarized in Table 1 . The coleus virus was not transmitted by $M$. persicae from infected to healthy coleus, or from infected $N$. benthamiana to either healthy coleus or healthy $N$. benthamiana. No symptoms developed in test plants 6 to 16 weeks post inoculation, and the virus was not detected by ISEM or DAS-ELISA in these plants. The New York coleus virus isolate was transmitted readily by mechanical inoculation to healthy $N$. benthamiana, and induced systemic mosaic symptoms indistinguishable from those caused by the Minnesota coleus virus.

Virion purification, CP size estimation, and serology. Based on TEM observation, UV absorption profile, and absorbance at 260/280 $\mathrm{nm}$ ratio (data not shown), suspensions of the coleus virus purified by isopycnic density gradient centrifugation in $\mathrm{Cs}_{2} \mathrm{SO}_{4}$ were judged to be free of host plant contaminants. The modal length of 117 PTA-stained particles was $640 \mathrm{~nm}$. The particles were similar in morphology to those of carlaviruses (9). A single capsid protein approximately $34 \mathrm{kDa}$ in size was detected by Coomassie Blue staining following SDS-PAGE of purified virions (Fig. 3). Rabbit antibodies raised against puri- fied virions reacted specifically with homologous antigen in DAS-ELISA and ISEM (trapping and decoration; data not shown). No serological or biochemical differences were detected between the Minnesota and New York coleus virus isolates.

Genomic sequence and phylogenetic analyses. A 2-kb fragment of the $3^{\prime}$ end of the coleus virus genome was cloned and sequenced (GenBank accession number DQ915963). This portion of the viral genome encoded putative proteins similar in size and arrangement to those of corresponding 3' region of carlaviruses (Fig. 4 ). These included open reading frame (ORF)3 (triple-gene block 2 [TGB2]; nucleotides 1 to 324), ORF4 (TGB3; nucleotides 303 to 509), ORF5 (CP) (nucleotides 610 to 1,527), ORF6 (nucleic acid binding protein; nucleotides 1,505 to $1,924)$, and a 14-nucleotide poly A tail (nucleotides 2,025 to 2,039). The overlap of ORF3/ORF4 and ORF5/ORF6 gap (Fig. 4) are characteristic of carlaviruses (8). The percent identity between the CP of the coleus virus and selected carlaviruses ranged between 34.7 and $64.1 \%$ based on amino acid identity (Table 2). The phylogenetic relationship between CVNV and these carlaviruses is represented in Figure 4. 


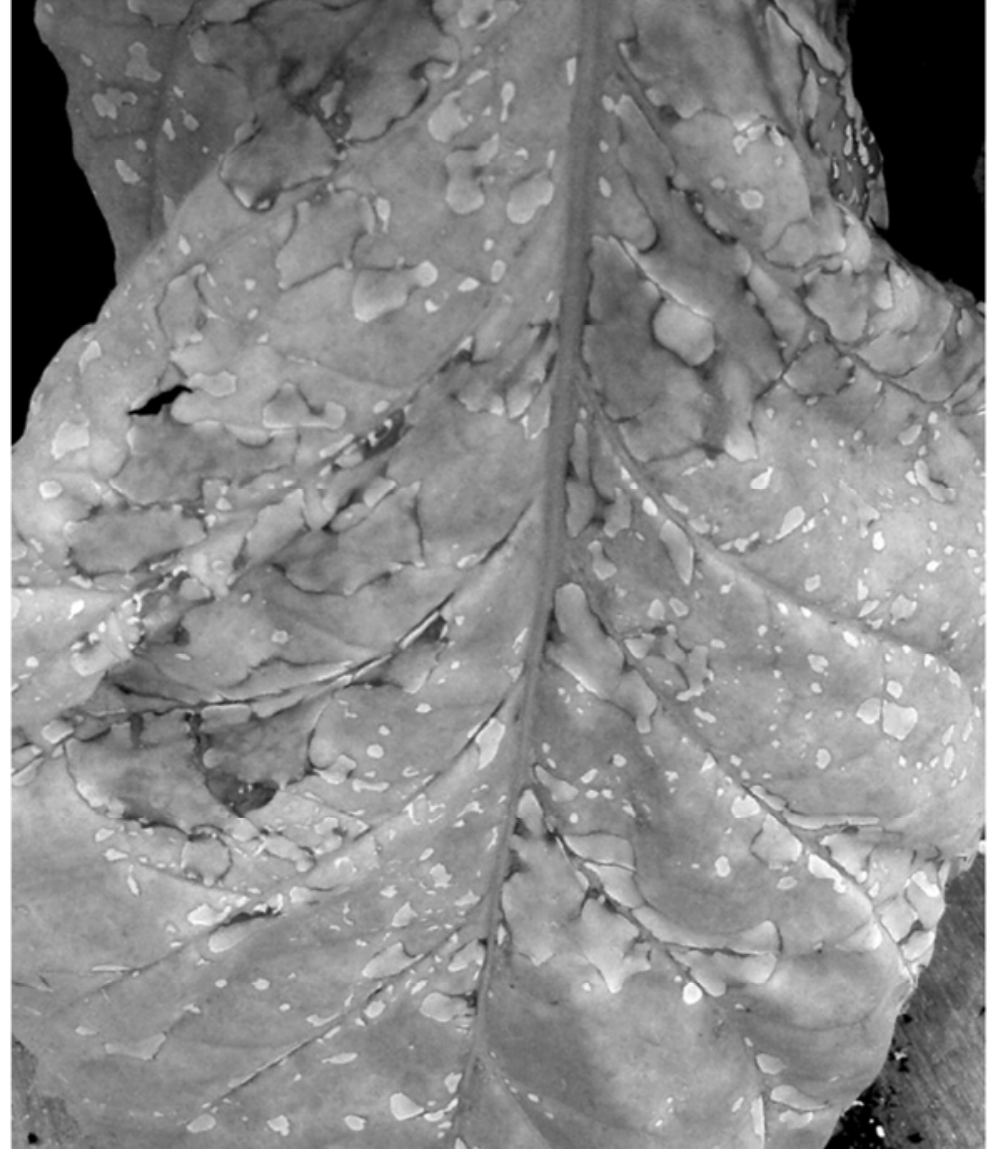

Fig. 6. Systemic necrotic symptoms induced by Coleus vein necrosis virus infection in Nicotiana tabacum.

\section{DISCUSSION}

Based on virion morphology, CP size, nucleotide, and amino acid sequence similarities, and on the number, size, and arrangement of the 3' ORFs, it was concluded that the coleus virus was a member of the genus Carlavirus. The phylogenetic analysis based on the $\mathrm{CP}$ amino acid sequence (Fig. 5) confirmed the taxonomic relatedness of the coleus virus to other carlaviruses, but the low degree of sequence identity (33 to 63\%), dictates that the coleus virus be recognized as a new and distinct species in the genus Carlavirus. The name Coleus vein necrosis virus (CVNV) is proposed for this virus in light of its association with this symptom in naturally infected coleus in which no other virus was detected (Fig. 1), and its ability to induce similar symptoms in healthy coleus infected by mechanical transmission from infected $N$. benthamiana (Fig. 2). The induction of systemic vein necrosis and necrotic ringspotting in N. tabacum (Fig. 6) suggests that this syndrome is characteristic of infection by CVNV. How- ever, the coleus plants from which CVNV was first isolated showed occasional yellow blotching, but never veinal necrosis, under average greenhouse conditions. Vein-necrosis symptoms were observed cultivar were grown under reduced light, when the leaves were light to medium green, rather than brightly colored and variegated. Failure of $M$. persicae to transmit CVNV indicates that this aphid is either a nonvector or else an inefficient vector of CVNV. Although this result does not preclude aphid transmission of CVNV, it suggests that spread of the virus may occur primarily through vegetative propagation. Mechanical transmission during handling of plants is also a possibility; however, we were not able to transfer the virus by pruning or handling. Therefore, managing infected plants before handling healthy ones during production does not seem likely to mechanically transmit the virus. Because vein-necrosis symptoms develop only under some growing conditions, it is possible that nonsymptomatic only when infected plants of the same
CVNV infection in coleus may be more widespread than is documented in this report. Coleus was only 1 of 12 genera in the family Labiatae that was susceptible to infection, yet CVNV infected three Nicotiana spp. (N. benthamiana, $N$. clevelandii, and N. tabacum; Fig. 6) readily and induced pronounced systematic symptoms but did not infect $N$. glutinosa or Petunia hybrida. Further investigation of the molecular or genetic basis for this restricted host range specifically may provide insights into this virus-host interaction.

\section{LITERATURE CITED}

1. Agrawal, Y. S., Pant, R. P., Lockhart, B. E. L., Srivastava, M., Chakraborty, N. K., and Varma, A. 1996. Association of a badnavirus with citrus mosaic disease in India. Plant Dis. 80:590592.

2. Altschul, S. F., Madden T. L., Schäffer A. A., Zhang J., Zhang Z., Miller W., and Lipman D. J. 1997. Gapped BLAST and PSI-BLAST: a new generation of protein database search programs. Nucleic Acids Res. 25:3389-3402.

3. Chen J., Chen J, and Adams M. J. 2001. A universal PCR primer to detect members of the Potyviridae and its use to examine the taxonomic status of several members of the family. Arch. Virol. 146:757-766.

4. Chen J., Chen J, and Adams M. J. 2002. Characterisation of some carla- and potyviruses from bulb crops in China. Arch. Virol. 147:419-428.

5. Clark, M. F., and Adams A. N. 1977. Characteristics of the microplate method of enzymelinked immunosorbent assay (ELISA) for the detection of plant viruses. J. Gen. Virol 34:475-483.

6. Currier, S., and Lockhart, B. E. L. 1996. Characterization of a potexvirus infecting Hosta spp. Plant Dis. 80:1040-1043.

7. Edgar, R. C. 2004. MUSCLE: multiple sequence alignment with high accuracy and high throughput. Nucleic Acids Res. 32:1792-1797.

8. Fauquet, C. M., Maniloff J., and Mayo M. A 2005 Virus taxonomy: classification and nomenclature of viruses. Pages 1101-1106 in: Eighth Rep. Int. Committee Taxonomy Viruses. Academic Press, Elsevier.

9. Franki R. I. B., Milne, R. G., and Hatta T. 1985. Atlas of Plant Viruses, Volume II. CRC Press, Boca Raton, FL.

10. Holcomb, G. E., and Valverde, R. A. 1991. Identification of a virus causing a mosaic on coleus. Plant Dis. 75:1183-1185.

11. Koenig, R., and Paul, H. L. 1982. Variants of ELISA in plant virus diagnosis. J. Virol. Methods 5:113-125.

12. Laemmli, U. K. 1970. Cleavage of structural proteins during assembly of the head of bacteriophage T4. Nature 227:680-685.

13. Singh R. P., Boucher A., and Singh A. 1991. High incidence of transmission and occurrence of a viroid in commercial seeds of Coleus in Canada. Plant Dis. 75:184-187.

14. Voigt, A. 1982. Season sales summary. Bedding Plant Ind. News. 13:1-4

15. Wrigley, N. G. 1968. The lattice spacing of crystalline catalase as an internal standard of length in electron microscopy. J. Ultrastruct. Res. 24:454-464. 